The International Journal of Social Sciences

Vol. 2, Issue. 3, Sept 2021

P-ISSN: 2807-193X | E-ISSN: 2746-4393

\title{
ANALYSIS OF MONETARY FACTORS ON THE INCOME OF COASTAL FISHERMAN'S IN THE COVID-19 WEST ACEH REGENCY
}

\author{
Leli Putri Ansari ${ }^{1}$ \\ University of Teuku Umar, Indonesia \\ leliputriansari@utu.ac.id \\ Ivon Jali| ${ }^{2}$ \\ University of Teuku Umar, Indonesia \\ Yasrizal $^{3}$ \\ University of Teuku Umar, Indonesia
}

\begin{abstract}
This research aimed to analyze fisherman's income according to monetary factors during covid-19 pandemic in coastal areas of West Aceh Regency in Aceh Province, Indonesia. This research applied cross-section data over 2021 by utilizing descriptive quantitative research and OLS model analysis (Ordinary Least Square). Research revealed monetary factors in term of the inflation of groceries price had negative influenced to the fisherman income at West Aceh Regency, mean while the variable of diesel price had positive influenced to fisherman income. During covid-19 pandemic, there was the increasing of groceries price (inflation) at 1,06 times or the consumer price index (CPI) of groceries price at 106 percent but the price of diesel was still same as before covid-19 pandemic because fisherman used subsidized fuel at Rp 5.150/liter. However, the quota of subsidized diesel did not fulfill the fisherman needs so that they must buy non subsidized diesel. It was impacted on the fishing operational cost which was bigger than fisherman income. Moreover, during covid-19 pandemic the average of fisherman income decrease at IDR 1.500.000-IDR 3.000.000 each trip compared with before covid-19 pandemic at IDR 5.000.000- IDR 7.000.000 each trip. It was caused by low fish price which was caused by the decreasing of fish demand.
\end{abstract}

Keyword: Fisher Income, Food Material Inflation, Price of Fuel coastal fishing

\section{A. Introduction}

Coronavirus Disease 2019 (COVID-19) is respiratory tract disease, which firstly detected at Wuhan China on 2019, which finally spreads to all around the world so that it became global pandemic. Covid 19 outbreak cause world economic has recession 
including Indonesia. Covid 19 Outbreak spread to Indonesia at the beginning of March 2020 through Indonesia government information and based on data obtained from Health Ministry of Republic Indonesia on November 2021 that the number of covid 19 cases reached 522.581 people in all of Indonesia area.

In order to prevent the spread of covid-19, Indonesia government released the policy of physical distancing and social distancing, work from home and large scale social restriction which was written on the regulation of Indonesia government No 21, 2020. As result, it impacted on all economic sector including fishery sector such as fisherman who stayed at Indonesia coastal areas and community who depend on the fishery sources. They perceived that that policy bothered local fisherman and fishery industry in marketing their catch. Then, the fisherman catch result got the quality decreasing or even becoming to rotten fish. Moreover, several cold storages had over stock because the fish can not be sold to the other regions as like usual. It effected on the significant decreasing of fish price till $50 \%$. It was not comparable with effort and operational cost used for fishing. As result, fisherman economic condition was getting worst.(Kholis et al., 2020)

It was also happened to the fisherman in West Aceh regency where it is west coastal areas of Aceh province. According to statistical center (2020) that the sea area of west Aceh regency is 12 mil equaled to $957,38 \mathrm{~km}^{2}$ so that it has big potential in fishery sector. As result, the number of West Aceh fisherman is bigger than the other regency in west south coastal area of Aceh province, Indonesia, which is known that Aceh Jaya regency has 1.010 fisherman, West Aceh regency has 3.500 fisherman and South west Aceh regency has 2.919 fisherman. (BPS, 2020)

Even though, there is big sources for fishery sector but the fisherman income was not able to fulfill life needs, so that the fisherman life in coastal area was not yet prosperous. Moreover, during covid-19 pandemic, new problem rise in West Aceh regency such as fish price fell which caused the decreasing of fisherman income. The closing of several areas caused fish supply chain disturb in this condition several coastal areas which did not have cold storage will waste the fish or sold it with low price to agent. This condition was very detrimental to fisherman because fish export from Aceh to the other areas stopped which was derived from low demand from Medan and export market, decreasing of fisherman activity which was caused by fishing operational cost used for buying fuel was not balance with fisherman income and that was monetary factor. The kind of operational cost paid by fisherman was cash out and non cash expenditures. The example of cash out were cost of fuel, oil, preservatives (ice and salt), 
Analysis of Monetary Factors on the Income of Coastal Fisherman's in the Covid-19...

crew consumption, retribution and taxes. Meanwhile, the example of non cash expenditures were the ship crew wages which was generally paid after sale. (Mulyadi, 2007)

Phenomena which was main problem of fisherman income was monetary factors compared with social economic and nature phenomena. Therefore, this phenomena was very interesting to be studied. Monetary factors will be studied such as groceries price which will be reflected on consumer price index and the price of fuel used for fishing activity during covid-19 pandemic. That monetary factors can influence fisherman income because groceries price portrayed on consumer price index and fuel price which was fishing production cost for fisherman who used motor vessel. If the price of groceries and fuel increase, it will effect on fisherman income because if they did not go to fishing, there will be no income. Monetary factors can be reviewed from groceries price which was reflected on the average price of goods and service consumed by the community (household) in one price index called consumer price index (CPI) and the increasing percentage of CPI named inflation. CPI was calculated every month to discover the goods price change in general, whether it is increasing or not, and based on that information inflation percentage can be known; whether it is high or low. Moreover, the kinds of goods and service can be grouped into seven groups according to Classfication of Individual Consumption by Purpose (COICOP). First group is food materials including grains such as rice, tubers, meat, fresh fish, egg, milk, vegetables, nuts, fruits, seasonings, and cooking oil. Second group was ready consumed food, non alcohol beverages, cigarettes, and tobacco. Third group was housing, electricity, gas, and fuels. Fourth group was clothing group. Fifth group was health such as medicines, physical treatment service. Next group was education, recreation and sport. The last group was transportation, communication and finance. (Natsir, 2014)

However, this research only discovers inflation from the food price change seen from CPI. To see the development of CPI to food material, beverage, and tobacco group Meulaboh city on 2020 during January until December can be seen in the following graph 2: 


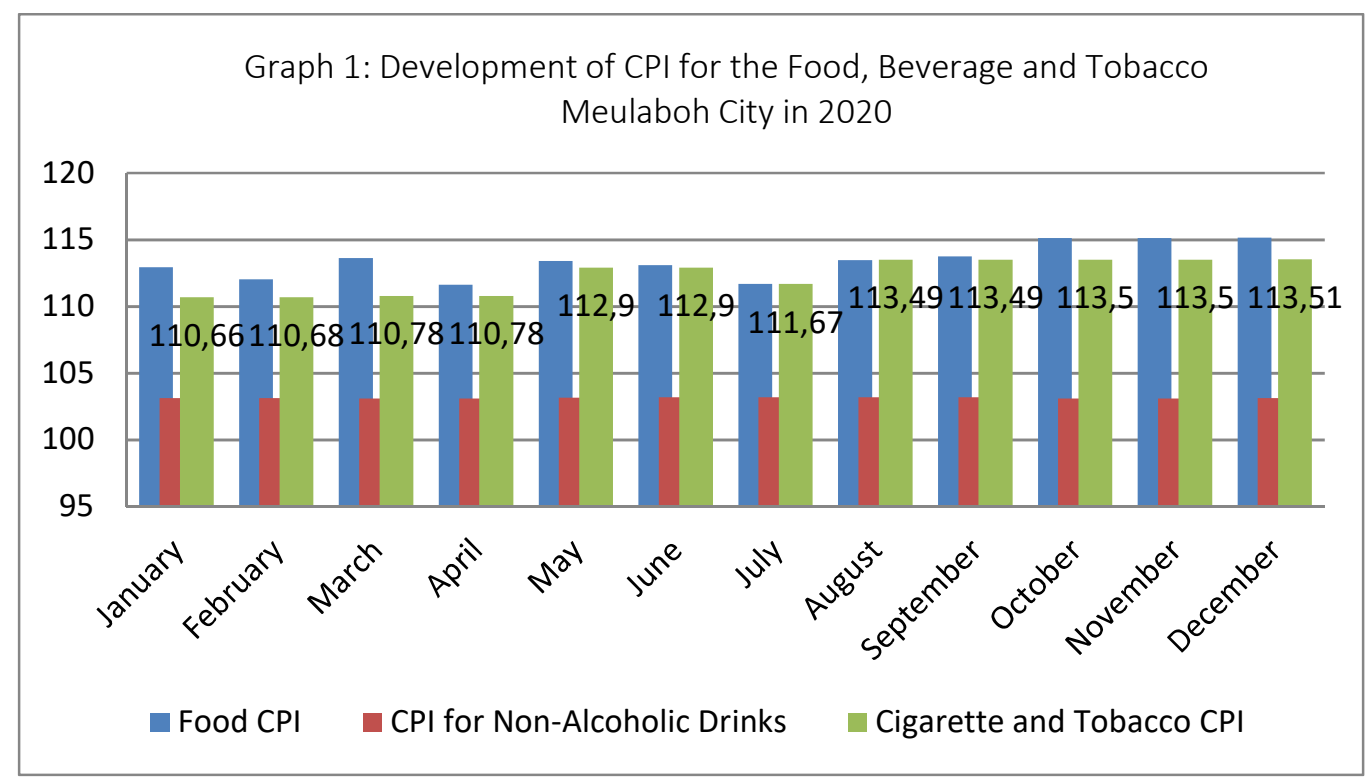

Source: BPS West Aceh Regency (2021)

Based on graph 1 related to CPI food, beverage, and tobacco group that inflation happen on food tobacco group, cigarette and tobacco group. Meanwhile non-alcohol had deflation. As result it needs to analyze whether the inflation happen on food group such as rice, egg, cooking oil and other food material and cigarette and tobacco group will impact on fisher income at coastal area of West Aceh Regency, where inflation on west south coastal area Aceh used Meulaboh inflation guidelines.

Besides, the food material, which influenced the fisher income, is fuel oil. Fuel oil utilized by motor boat is diesel fuel, which is main capital for fisher to go fishing. The prices of fuel, which often fluctuate make fisher difficult, predict the amount of fishing production cost. Even government gives fuel subsidy to fisher but the quota is not sufficient. The price of diesel is IDR 5.150 per liter during January until December 2020. However, the development of non-subsidy diesel price on 2020 can be seen in the following table 1 :

Table 1. Adjustment of Selling Prices for Types of Gasoline and Diesel Channeling through Fishermen's Fuel Filling Stations in January-September 2020

\begin{tabular}{lcc} 
Types of gasoline and diesel fuel & $\begin{array}{c}\text { Before Price Adjustment } \\
\text { (IDR) per Liter }\end{array}$ & $\begin{array}{c}\text { After Price Adjustment } \\
\text { (IDR) per Liter }\end{array}$ \\
\hline Pertamax & 9.850 & 9.200 \\
Pertamax Turbo & 11.200 & 9.990 \\
Pertamina Dex & 11.700 & 10.200 \\
Dexlite & 10.200 & 9.500 \\
Solar Non Subsisi & 9.600 & 9.300 \\
\hline
\end{tabular}


Source: PT.Pertamina (Persero)

The price of fuel on table 1 is the price of non-subsidy fuel and non-subsidy diesel which have been adjusted on price by Pertamina Company in all Indonesia are since January $5^{\text {th }} 2020$ in implementation of Ministry Decision ESDM 187K/10/MEM/2019 including Aceh province. Prior to this adjustment, the price of fuel and diesel in some area was not same because it is influenced by the amount difference of tax fuel. After adjustment of fuel price, the price is decreased. So that it needs to analyze through this research whether price change of fuel and diesel effect on the increasing of fisher income in coastal area of West Aceh Regency.

\section{Literature Review}

\section{Fisher Definition}

Fisher is someone who works by catching the fish. Then, fisher can also be differentiated based on the following thing: (Apridar et al., 2011)

a. Fisher based on the fishing tools

1) Fisher with properties means fisher who has fishing tool whether directly catch the fish or lease his fishing tools to others.

2) Fisher as worker means fisher who does not have fishing tool but they rent it from other or they work to someone who has fishing tools.

b. Fisher based on work time

1) Full time fisher is fisher, who has fishing tool or not, only works in fishery sector without any other job.

2) Part time fisher means fisher, who has fishing tool or as worker, has another job.

c. Fisher based on position

1) The boss of fisher is fisher who has fishing tool i.e. boat and net

2) Worker means fisher who operates fishing tool, which is not his property, or fisher who only has simple fishing tool. Usually, this worker has low education effected on the unknown of market price so that they are stuck in poverty.

d. Fisher based on the using of fishing technology

1) Traditional fisher is fisher who utilizes rowing boat, motor boat with the biggest size 5 gross tonnages (GT) and using trawl, fishing line, ganyang, rempa, cawo and sungkur as fishing tools.

2) Semi modern fisher is fisher who still uses traditional machine tool in catching the fish with boat size above 5-8 GT. 
3) Modern fisher means fisher who uses motor boat with fishing technology i.e. 100 PK machine with 5-10 GT until 200 GT capacity.

\section{Definition of Fisher Income}

Fishermen's income is the difference between revenue and fishing costs that are actually spent per trip or per year. In other words, fishermen's income is all the income received by fishermen's households from fishing in the sea after conducting sale and purchase transactions between fishermen as producers and buyers as consumers and transactions between fishermen (producers) and fish dealers (distributors). (Lasut et al., 2019). In general, off shore fishing that is carried out for a longer time and is further from the target area of the fish catchment has a higher probability of obtaining a higher catch (production) and of course provides a higher income compared to near-shore fishing. (Dahen, 2016)

\section{Monetary Phenomena}

Monetary phenomena based on monetarist thought that inflation can be stated as monetary phenomena because inflation caused by money supply growth as result there is price change but the output was constant. Meanwhile, structuralist explained inflation was long term monetary phenomena emphasized on strict economic structure especially developed country. (Hervino, 2011, p. 140).

\section{Inflation Theory}

Inflation is the price increasing process of things continuously. It does not mean the price of variety tool is increasing with same percentage. Increasing happens in one time even though high enough percentage is not inflation. The price increasing is measured with price index. Some prince index is often used to measure inflation included consumer price index, wholesale price index and Gross National Product (GNP) deflator. (Silalahi, 2013:214-224).

\section{The Price of Fuel Oil}

The price of fuel oil is some monetary value, which determined to get one oil barrel. The increasing of fuel oil price effect fishery decreases the produced output. It happens because the price increasing of fuel oil makes the production cost increase. (Arifah, 2020, p. 25). There are some effect of fuel oil price increasing on fisher:

a. Price increasing of fuel oil will decrease the number of produced fish so that the price of fish at market will increase. (Wunawarsih, 2015)

b. The price increasing of fuel oil is clearly affected on many people. For example, with price increasing on premium or solar as fisher transportation fuel cause the 
increasing of production cost. The increasing of production cost will push the sell price of output. (Sabar \& Indasari, 2018)

\section{Hypothesis}

The hypothesis tested in this study is that it is assumed that the monetary phenomenon in terms of inflation of food stuff prices and diesel fuel prices has a correlation with the income of fishermen in coastal areas in West Aceh Regency.

\section{B. Research Methods}

\section{Population and Sample}

The population in this study were all fishermen who use motorboats in West Aceh Regency which are located in Johan Pahlawan District, Bubon District, and Meurebo District as many as 1.784. Furthermore, the number of samples as many as 89 respondents was taken 5 percent of the total population in order to obtain a sample size that was not too large. The sampling technique uses incidental sampling, namely motor boat fishermen who are met by chance to meet the researcher can be sampled if the person is suitable as the data source. (Sugiyono, 2016) which can be seen on Table 2.

Table 2 . Number of Pupolations and Samples in Coastal Areas

From West Aceh Regency Year 2021

\begin{tabular}{|l|l|c|c|}
\hline No & \multicolumn{1}{|c|}{ Districts } & Population & $\begin{array}{c}\text { Sample 5\% of the } \\
\text { Population }\end{array}$ \\
\hline 1 & Johan Pahlawan & 887 & 44 \\
\hline 2 & Samatiga & 456 & 23 \\
\hline 3 & Meurebo & 441 & 22 \\
\hline & Jumlah & 1.784 & 89 \\
\hline
\end{tabular}

Source: BPS West Aceh Regency (2021)

\section{Scope of the Research}

This research did at Johan Pahlawan Subdistrict, Sama Tiga Subdistrict, Meurebo Subdistrict in West Aceh Regency. Those areas were chosen with consideration that that three are located in Coastal Area. This research on 2021, by using descriptive quantitative approach and using cross section data. (Sugiyono, 2016)

\section{Data Analysis Model}

Data analysis model used double linear regression through OLS (Ordinary Least Square) with the following formulation of equation model: 
$P N P=a+b F M I H B M+c F M H B B M+e$

Then, in order to make data tabulation easy because the variable unit of food price inflation, fuel price, and income are different so equation model (3.1) transformed into natural logarithm model (Ln), which can be write as follow:

$\operatorname{LnPNP}=\mathrm{a}+\mathrm{b} \mathrm{FMI}_{\mathrm{HBM}}+\mathrm{c} \operatorname{LnFMH}_{\mathrm{BBM}}+\mathrm{e}$

$\begin{array}{ll}\text { PNP } & =\text { Fisher Income } \\ \text { FMIHBM } & =\text { Monetary Factors (the inflation of food material price) } \\ \text { FMHBBM } & =\text { Monetary Factors (Fuel Price) } \\ \mathrm{a} & =\text { Constant } \\ \mathrm{b} & =\text { Variable regression coefficient of food material price } \\ \mathrm{C} & =\text { Variable regression coefficient of fuel price } \\ \mathrm{e} & =\text { Distracter mistake }\end{array}$

4. Framework

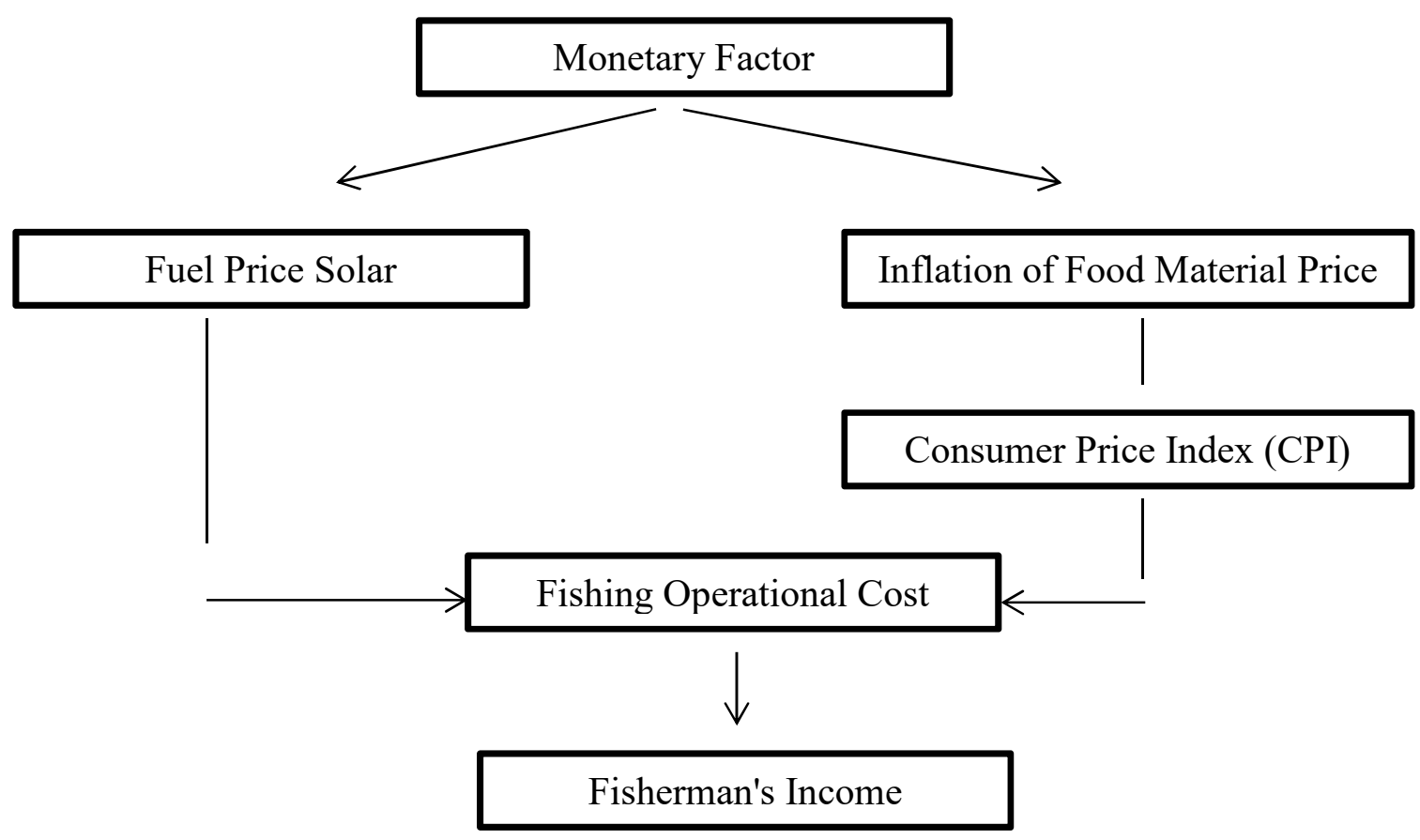

\section{Hasil dan Pembahasan}

Although natural resources for capture fisheries in Aceh Barat Regency are abundant, as seen from fish production, coastal communities who live as fishermen have 
low incomes, even below the minimum wage. This can be seen from the following graph 3:

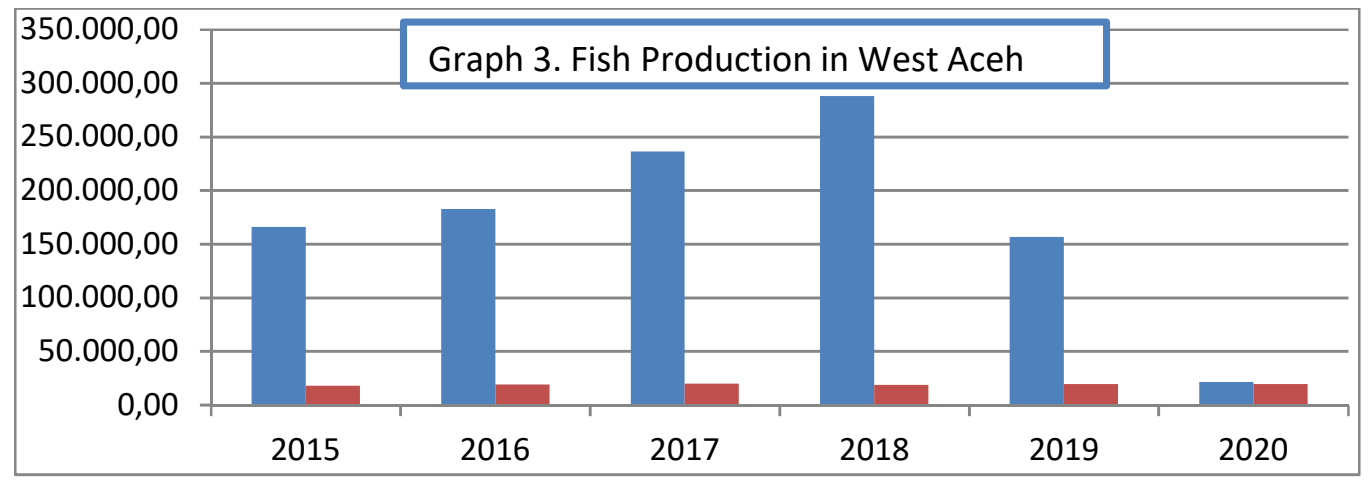

The portrait of fisherman life at coastal areas of West Aceh Regency is small scale fishermen capitalizing labor and simple fishing tools, having low education degree, having minimum market information, the roles of skipper was big in their social economic life both in production and marketing or even in fulfilling daily needs. As result, it was known that fisherman life was still far from prosperity. During covid-19 pandemic fisherman life in West Aceh Regency was worst because the fisherman income was lower caused by cheap fish price compared with before civid-19 pandemic. The comparison of fish price before and during pandemic can be seen in the following Table 3.

Table 3. Comparison of Fish Prices Before Covid-19 and When Covid-19 Occurred in West Aceh Regency

\begin{tabular}{clcc}
\hline \multirow{2}{*}{ No } & \multicolumn{2}{c}{ Types of Fish } & \multicolumn{2}{c}{ Fish Price (IDR) /Kg } \\
\cline { 3 - 4 } & & Before Covid-19 & Covid-19 \\
\hline 1 & Red snapper (Lutjanus campechanus) & 60.000 & 30.000 \\
2 & Mackerel (Scomber scombrus) & 15.000 & 7.000 \\
3 & Anchovy (Stolephorus commersonii) & 8.000 & 3.000 \\
4 & Tuna fish (Thunnus) & 55.000 & 22.000 \\
5 & Cob fish (Euthynnus sp) & 15.000 & 4.000 \\
6 & Dencis (Sardinella melanostica) & 25.000 & 9.000 \\
7 & Kingfisher (Alepes melanoptera) & 5.000 & 3.000 \\
8 & Pike (Scomberomorus guttatus) & 10.000 & 6.000 \\
\hline
\end{tabular}

Source : Primary Data (2021)

Based on Table 3 that the types of fish that are often caught by fishermen in the coastal areas of West Aceh Regency are ikan kakap merah, ikan kembung, ikan tuna, ikan tongkol, ikan dencis, ikan dodok dan ikan kacangan. The price of fish during the covid-19 
pandemic decreased by an average of 50 percent compared to before the covid-19 pandemic.

During covid-19 pandemic, fisherman fishing result in West Aceh regency was same as before covid-19 or even more. However, fish demand decreased both from consumer and restaurant and fish processing industry. As result, fish was unable to collect and many rotten fish wasted in river side. This condition caused fisherman income decreased in West Aceh Regency.

Based on the finding which was collected by interviewing 89 respondent, it was revealed that monetary phenomena occurred on fisherman in West Aceh regency located on Johan Pahlawan district, Samatiga, and Meureubo during covid-19 pandemic was same. If it was reviewed from inflation (CPI), it revealed there was increasing of groceries price (rice, sugar, cooking oil, egg and cigarette) at 106 percent or 1,06 times on 2020 compared with 2019 and it means the inflation of groceries prices before covid19 pandemic was $100 \%$. Meanwhile, if it was reviewed from the price of fuels that is, the limitation of fuel stock for fisherman at Refueling station for fisherman was 5 tons each day and amount of diesel stock did not able to fulfill the needs of motor vessel in West Aceh regency. It impacted on the fisherman income especially small scale fisherman because they go fishing everyday, go and back at the same day, by using 3-5 GT (gross tonnage) motor vessel. Small scale fisherman only get 500 liter diesel or half ton each day and they will not get more diesel tomorrow so that they have to buy diesel from big fisherman with expensive price for fishing at the next day. Monetary phenomena was burdensome for fisherman during covid-19 pandemic, because the price of fish was really cheap so that fisherman income decreased impacted on their inability to pay the debt which was lent as fishing capital to buy groceries and diesel fuel.

For the number of diesel fuel needed by motor vessel fisherman depend on the kind of motor vessel and fishing distance, it can be seen in the following Graph 2:

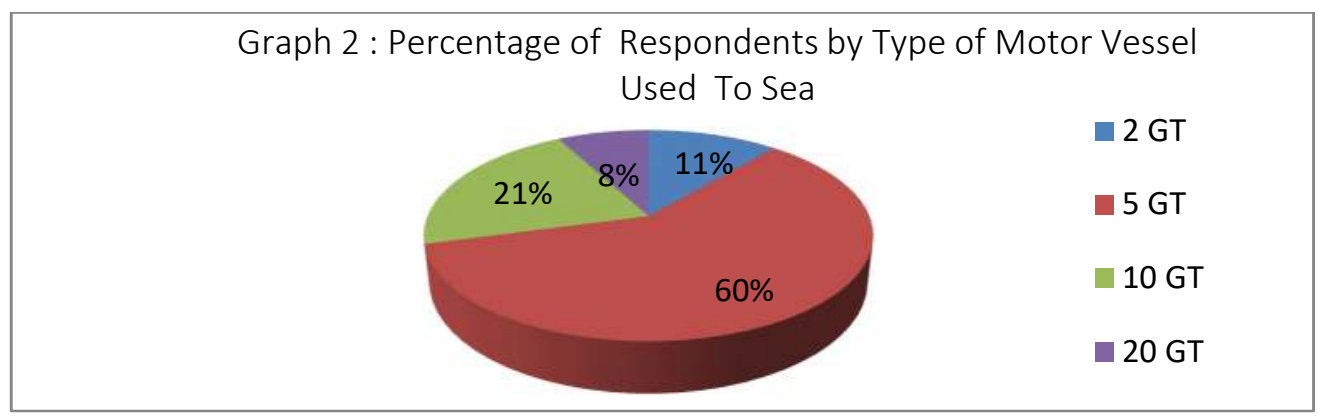

Source : Primary Data (2021) 
Based on graph 2, the majority of fisherman at coastal areas of west Aceh regency was small scale fisherman (60 percent) using 5 GT motor vessel, wherein they go fishing everyday. Even during covid-19 pandemic small scale fisherman was still going fishing, because if they did not go fishing, they would not get the income.

The income earned by fishing fishermen in 2021 is an average of 1,000,000 $5,000,000$ IDR/trip, which $64 \%$ is a traditional fisherman and this income will still be a gross income that has not been deducted by operational costs and wages of crew members. Meanwhile, $21.74 \%$ are semi-modern fishermen with an income of IDR $6,000,000$ - IDR 11,000,000/trip. The income of these capture fishermen is starting to stabilize compared to 2020, the income of fishermen is 1,500,000-3,000,000 IDR/trip. This is because in 2020 the onset of the covid-19 pandemic and in 2021 the status of the pandemic is heading to new normal, where in normal times before the covid-19 pandemic the average income of fishermen reached IDR 5,000,000-IDR 7,000,000/trip. it can be seen in the following Graph 3:

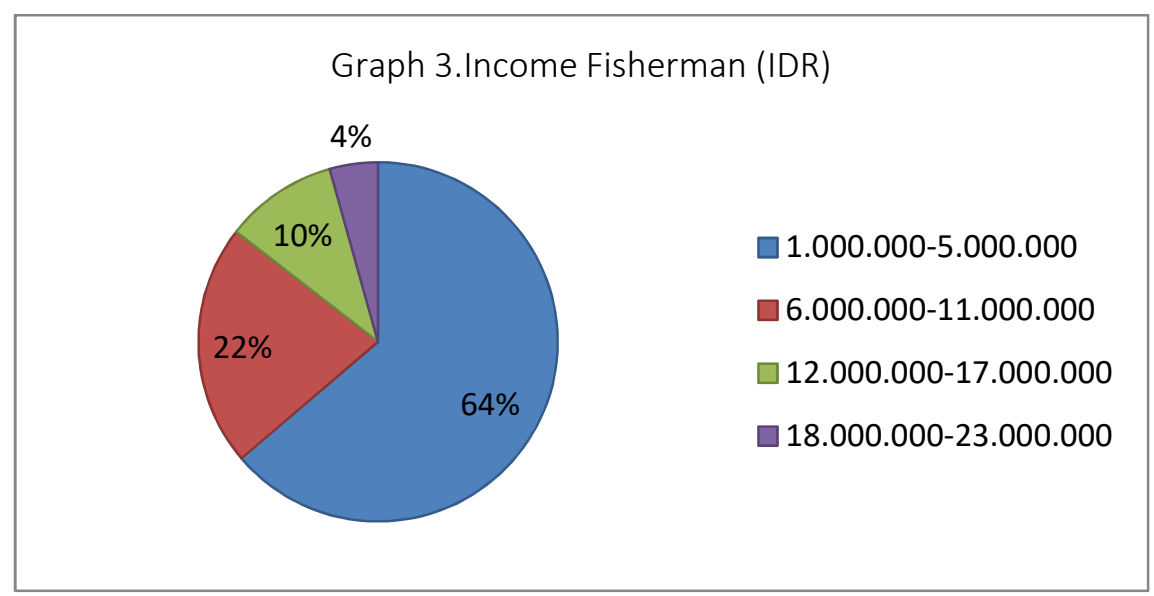

Source : Primary Data (2021)

Then, to discover the impact and correlation of monetary factors (inflation of groceries price) and the fuel price to fisherman income can be seen in the following Table 4:

Table 4. Estimation is Results

\begin{tabular}{|l|c|c|c|c|c|c|c|c|c|}
\hline $\begin{array}{c}\text { Independent } \\
\text { Variable }\end{array}$ & $\begin{array}{c}\text { Regression } \\
\text { Coefficient }\end{array}$ & $\begin{array}{c}\mathrm{T} \\
\text { Count }\end{array}$ & Sig & $\begin{array}{c}\mathrm{T} \\
\text { table }\end{array}$ & $\alpha$ & $\begin{array}{c}\mathrm{F} \\
\text { count }\end{array}$ & sig & $\begin{array}{c}\mathrm{F} \\
\text { table }\end{array}$ & Sig \\
\hline $\begin{array}{l}\text { Food Price } \\
\text { Inflation }\end{array}$ & $-0,039$ & $\begin{array}{c}- \\
\text { Prices for } \\
\text { Diesel Fuel }\end{array}$ & 0,689 & 0,581 & $\begin{array}{c}- \\
1,833\end{array}$ & 0,05 & & & \\
\hline
\end{tabular}




\begin{tabular}{|l|l}
\hline $\mathrm{R}^{2}$ & 0,755 \\
Adjusted $\mathrm{R}^{2}$ & 0,701 \\
\hline
\end{tabular}

Source : Regression Output (2021)

Based on Table 4 , the estimation equation can be written as follows:

$$
\operatorname{LnPNP}=7,292-0,039 \mathrm{FMI}_{\mathrm{HBM}}+0,851 \mathrm{LnFMH}_{\mathrm{BBM}}+\mathrm{e}
$$

On equation (3) it can be explained that partial test (T-test) for inflation variable of food material price is obtained $T$ value $=-0,689$ which bigger that $T$ table $=-1,833$. so it can be concluded that the inflation of food material price is having negative influence to fisher income which used motor boat in West Aceh Regency but it was not significance on level $5 \%$. It is caused during covid 19 pandemic the increasing of food material price caused physical distancing and social distancing. It influenced the fishing operational cost. Production cost paid by fisher such as the price of fuel, ice, salt, and food supply. When the price increasing on food supply, fisher will decrease the number of food buying such as; rice, instant noodle, sugar, coffee, and cigarette. However, they give priority to buy sugar, coffee, and cigarette because coffee and cigarette can tolerate hungry and reducing fishing time i.e. 15-20 days before pandemic becoming 3-5 days so that it is influenced to fisher income. Unfortunately, the number of fish was almost same with day before pandemic 300-500 ton because they have recognized the fish location, which has many fish, and the number of fish obtained depended on west and east wind season. Because the price of fish decrease so that the fisher income also decrease i.e. IDR 1.500.000-IDR 3.000.000 rather than their income before covid 19 pandemic reached IDR 5.000.000-IDR7000.000. though fisher income is net income accepted after reducing production cost. Nevertheless, fisher income is divided with the owner of motor boat, ship crew, and sea guard. The pattern of sharing profit that accepted by ship crew and the owner is a half and the profit obtained by ship crew should be divided with the other worker.

Meanwhile the variable of diesel price was having positive influence to motor boat fisher and it is significance on level 5 percent, which showed by the value of $t$ count $(5,114)$ bigger that the value of tabel $(1,833)$ and it was not significance because the significance is bigger $(0,001)$ smaller than significance level 0,05 percent. It can be explained that the diesel used by motor boat is subsidized diesel. So that if the price of diesel increase still go to fishing. It will become barrier for fisher. as result to save diesel fisher join with other fisher to used one motor boat. Fish resulted was much but the price 
of fish is cheap so they sell half of them to fish procession entrepreneur such as salted fish, kemamah paid with normal price because salted fish and kemamah were souvenirs from West Aceh Regency

Based on the variable simultaneous test, the food supply inflation and diesel variable is influenced to the income of motor boat income in West Aceh Regency.

\section{Conclusions and Suggestion}

\section{Conclusions}

Based on the research finding that food material inflation had negative influence to fisher income used motor boat but it was not significant. Meanwhile the price of diesel had positive influence to fisher income and it was significance. The fisher income during covid 19 pandemic decrease because the fish price low even though the number of fish and fish caught depend on the wind season. Meanwhile on east wind season most of the fish are teri fish, shrimp, lobster, kappa-kapas fish and tuna. The mean of fisher income during covid 19 pandemic is IDR 1.500.000-IDR 3.000.000 per trip. Those low income make fisher become stuck in poverty, because the income obtained can be saved but they spend it for family consumption and paying loan.

\section{Bibliography}

Apridar, Karim, M., \& Suhana. (2011). Ekonomi Kelautan Dan Pesisir. Graha Ilmu.

BPS. (2020). Aceh Barat Rgency in Fgures. BPS-Statistics of Aceh Barat Regency. https://doi.org/1102002.1107

Dahen, L. (2016). Analisis Pendapatan Nelayan Pemilik Payang Di Kecamatan Koto Tangah Kota Padang. Journal of Economic and Economic Edication, 5. https://doi.org/http://dx.doi.org/10.22202/economica.2016.v5.il.891

Kholis, M. N., Fraternesi, \& Wahidin, L. O. (2020). Prediksi Dampak Covid-19 Terhadap Pendapatan Nelayan Jaring Insang Di Kota Bengkulu. ALBACORE Jurnal Penelitian Perikanan Laut, 4(1), 001-011. https://doi.org/10.29244/core.4.1.001-011

Lasut, S. J., Rotinsulu, D. C., \& Engka, D. S. M. (2019). Analisis Pengaruh Harga Bahan Bakar Minyak Dan Perubahan Cuaca Terhadap Pendapatan Nelayan Di Kecamatan Tuminting Manado. Jurnal Pembangunan Ekonomi Dan Keuangan Daerah, 18(1). https://doi.org/10.35794/jpekd.10764.18.1.2016

Mulyadi. (2007). Ekonomi Kelautan. RajaGrafindo Persada.

Natsir. (2014). Ekonomi Moneter \& Kebansentralan. Mitra Wacana Media. 
Sabar, W., \& Indasari, N. (2018). Determinan Tingkat Pendapatan Nelayan Perahu Motor Tempel. Ecces (Economics, Social, and Development Studies), 5(1), 43. https://doi.org/10.24252/ecc.v5i1.5236

Silalahi, R. (2013) Macroeconomy of Theory. Bandung: Citapustaka Media Perintis

Sugiyono. (2016). Metode Penelitian; Kuantitatif, Kualitatif, dan R \& D. Alfabeta.

Wunawarsih, I. A. (2015). NELAYAN DI KELURAHAN SODOHOA KOTA KENDARI Content Analysis of BBM Price Increases at Kendari Post Daily and The Impact in to The Number of Fishermen at Sodohoa Sub District Kendari City 3(2), 145-154. 